\title{
Myroslava Antonovych
}

\section{SPECIFIC INTENT (DOLUS SPECIALIS) IN THE ARMENIAN GENOCIDE, THE HOLODOMOR AND THE HOLOCAUST: COMPARATIVE ANALYSIS}

\begin{abstract}
Although comparative genocide as the second generation of genocide studies has developed over the past two decades, the Holodomor as a crime of genocide committed by Stalin's regime has not been examined in comparative perspective. In this article, the author traces the reasons for that and offers a comparative analysis of the Holodomor with examples of genocide in the first half of the $20^{\text {th }}$ century - namely, the Armenian genocide of the Ottoman Empire and the Holocaust of Nazi Germany. The author compares the three genocides as crimes under international law in terms of the mental (mens rea) elements of genocide that characterize each of them, noting the dissimilarities and similarities in specific intent (dolus specialis) of those crimes. The author draws to the conclusion that the key common element in the genocides perpetrated in the Ottoman Empire, the Soviet Union, and the Third Reich is that state organization was substituted by hegemony of a ruling party: the Ittihadists, the Communists, and the Nazis. The importance of comparing cases of genocide is evident: if lessons from the past are not heeded and genocide is not punished, history will repeat itself as can be seen in the east and south (Crimea) of Ukraine, where the successor state to the Soviet Union - the Russian Federation - continues an attack on the Ukrainian nation.
\end{abstract}

Keywords: the Armenian Genocide, the Holodomor, the Holocaust, mental elements of genocide, specific intent (dolus specialis) of genocide.

\section{Introduction}

Although comparative genocide as the second generation of genocide studies has developed over the past two decades, the Holodomor as a crime of genocide committed by Stalin's regime against the Ukrainian nation has not been examined in comparative perspective. Meanwhile it is important to compare the Holodomor with other examples of genocide in the first half of the 20 century - namely, the Armenian genocide of the Ottoman Empire and the Holocaust of Nazi Germany in terms of the mental (mens rea) and material (actus reus) elements of genocide that characterize each of them. In my article, I will compare specific intent (dolus specialis) in the three genocides, noting the dissimilarities and similarities in intent to commit these international crimes.

Some steps in comparative analysis of the three genocides under examination were made and the topics for such analysis were outlined. Thus, Frank Sysyn wrote in 1999 that "for those studying the Armenian genocide, examination of the Ukrainian famine offers considerable comparative material. This discussion of both tragedies has involved questions of intent and evidence. Both have been surrounded by controversies over the number of victims and the definition of genocide" [28, p. 202-203].
Stanislav Kul'chyts'kyi attempted to examine the ways in which the Holodomor differed from the Holocaust and argued that the ideology behind murder carried out by the Stalinist state were different" [16, p. 89]. S. Kul'chyts'kyi made a claim that "Stalin was motivated by class considerations, while Hitler by the national. Class-based destruction led to the Holodomor; nation-based destruction led to the Holocaust" [16, p. 89]. The question arises why the "class-based destruction" in the Soviet Union led to the Holodomor only in Ukraine and the North Caucasus region with majority of the Ukrainians. If the intent only entailed class-based destruction, the events would not be confined to a concrete territory but would be throughout the Soviet Union. S. Kul'chyts'kyi's statement that "the Ukrainian Holodomor, unlike the Holocaust, was the result of certain circumstances coinciding in time and place" [16, p. 108], from the legal point of view, from the view of elements of the crime of genocide should also undergo criticism.

Benjamin Lieberman provided a short comparative analysis of the Holodomor with the Holocaust and the Armenian genocide and claimed that the famine or the Holodomor in Ukraine both shared key elements of genocide and diverged from some of the cases of genocide in twentieth-century 
Europe [18, p. 96]. He concluded that "key elements of the famine in Ukraine fell under genocide as later anchored in international law. Predictable death from starvation repeated at least in part one of the major methods used to kill Armenians off. Also, while the initial campaign against Kulaks began by targeting enemies identified by the class position, national, economic, and political categories overlapped as the Soviet leadership saw famine as evidence of Ukrainian national resistance to collectivization, and the policies that magnified the effects and the losses from famine focused on Ukraine in particular" [18, p. 96].

However, with few exceptions, in contrast to the Armenian genocide and the Holocaust, the Holodomor thus far has not been included in comparative surveys of genocide for different reasons. First, for more than fifty years, it was a hidden genocide, which was denied by the Soviet Union, and only the Ukrainian diaspora, mainly in Canada and the USA, spoke out and revealed the truth about this crime. Second, most of those scholars who agreed that there was a great manmade famine in Ukraine enlisted it among Stalin's crimes, majority of which (dekulakization, deportations, extermination of political opponents, etc.) do not fit the legal definition of genocide given in the 1948 UN Convention on Prevention and Punishment of the Crime of Genocide (The Genocide Convention). Third, only during the last decades after the Soviet archives were open, a consensus among a substantial group of scholars has evolved that "the Ukrainian Famine of 1932-1933 fits the general template of genocide" [21, p. 112].

Rafael Lemkin, the father of the Genocide Convention, who invented the term "genocide," characterized the Kremlin policy in Ukraine in the first half of the $20^{\text {th }}$ century as "the classic example of the Soviet genocide, its longest and broadest experiment in Russification - the destruction of the Ukrainian nation" [17, p. 31]. Since then many scholars referred the Holodomor to crimes of genocide $[3 ; 11 ; 19 ; 20 ; 25$ etc.]. However, in almost all publications about the Holodomor the emphasis remains on its in depth analysis, and not on its comparison to other genocides. Even the scholarly works that specifically discuss the Holodomor through a genocidal lens, such as Robert Conquest's "Harvest of Sorrow" [6], tend to focus on the Holodomor as a stand-alone case.

This article will highlight only mens rea element of the crime of genocide in the three cases under comparison. For that reason, it does not go into details of the other elements and their presence in the genocidal crimes of the Holocaust, the Holodomor and persecution of Armenians in the Ottoman empire.

Mental Elements of the Armenian genocide, the Holodomor and the Holocaust

In the Rome Statute of the International Criminal Court (ICC) and in the document "Elements of Crimes" ICC distinguished between mental (mens rea) and material (actus reus) elements of the crimes, inter alia, of a crime of genocide over which ICC has jurisdiction. "A person shall be criminally responsible and liable for punishment for a crime within the jurisdiction of the Court only if the material elements are committed with intent and knowledge. Where no reference is made in the Elements of Crimes to a mental element for any particular conduct, consequence or circumstance listed, it is understood that the relevant mental element, i.e., intent, knowledge or both, set out in article 30 applies" [8]. According to Article 30 of the Rome Statute, "a person has intent where: (a) In relation to conduct, that person means to engage in the conduct; (b) In relation to a consequence, that person means to cause that consequence or is aware that it will occur in the ordinary course of events" [23].

Thus, mental elements of genocide include the intent and knowledge. As Machteld Boot writes, the prevailing interpretation as regards the question of intent as included in the Genocide Convention assumes that genocide is a crime of specific or special intent (dolus specialis), involving a perpetrator who specifically targets victims on the basis of their group's identity [4, p. 410]. It is reasonable to compare the cases of genocide under examination in accordance with the specific intent element of genocide in them.

In all three cases, there was intent to destroy a relative group, either in whole (the Armenians and Jews) or in part (the Ukrainians), in the latter case just because the Ukrainian national group was, as R. Lemkin stressed, "too populous to be exterminated completely with any efficiency. However, its leadership, religious, intellectual, political, its select and determining parts, are quite small and therefore easily eliminated" [17, p. 32]. B. Lieberman makes a similar point: "The perpetrators of the Holocaust aimed for the destruction of European Jews, and the goals were nearly the same for Armenians, albeit with partial exception for a few urban communities as well as for converts. In the Soviet Union, in contrast, the Soviet leadership was willing to accept a pulverized, weakened and devastated Ukrainian population without actually seeking to destroy the 
Ukrainian presence. Sending new settlers to Ukraine altered but did not completely overturn the demographic balance in Ukraine" [18, p. 96-97].

Difference in the type of intent in the Armenian genocide, the Holodomor and the Holocaust

The type of the intent differed in the three cases under analysis. While in the Armenian and in the Jewish cases, the intent was explicit (mainly formulated in documents), the intent to commit the Holodomor was implicit. Yet even being explicit, the intent of Nazis to exterminate Jews was not directly formulated in orders. As Charles W. Sydnor, Jr. wrote, "However carefully the document for Hitler might have been composed, with elliptical phrasing and with already familiar euphemisms, the tone and language probably would have conveyed the intent of destruction as the result of years of planning and preparation, as the outgrowth of cumulative experience" [27, p. 175; 26, p. 67].

In the absence of evidence of explicit orders, Thomas W. Simon notes the importance of inferring intent in the Nazi cases from the proceedings at the Wannsee Conference and other acts taken on behalf of the Third Reich [26, p. 67]. He claims that "in the Nazi case, a plethora of declarations and classifications contained in various documents provided the voluminous paper trail needed to infer intent to commit the crime of genocide. Each act, each bureaucratic maneuver filled in a small fragment of the large mosaic of intent... The German railroad even meticulously billed the Security Police for the one-way fare of the deportees for their journey to the death camps" [26, p. 67].

Helen Fein refers to statements of Turkish officials to protesting diplomats as evidence of intent published in the British Blue Book, namely to an interview with Talaat Bey (one of the ruling triumvirate) in 1916 in the Berliner Tageblatt: "We have been reproached for making no distinction between the innocent Armenians and the guilty; but that was utterly impossible, in view of the fact that those who were innocent today might be guilty tomorrow" (Bryce and Toynbee 1916, 633...). US Ambassador Henry Morgenthau protested in Constantinople to Talaat (who also assured him that their policy was to eliminate all Armenians)" [9, p. 12].

The intent of Stalin and his henchmen to exterminate Ukrainians in part was implicit and differed from intent in the previous cases. As the International Criminal Tribunal for the former Yugoslavia (ICTY) formulated in the Jelisić case in 1995: the "genocidal intent can take two forms": on the one hand, the intent to exterminate a very large number of members of the group, and, on the other hand, the intent to pursue a more selective destruction targeting only certain members of the group "because of the impact their disappearance would have on the survival of the group as such" [14, para. 82].

Such intent of the Communist Party to selectively exterminate Ukrainians, as R. Lemkin wrote, appeared from beginning of 1920s, when in 1920 , 1926, and again in 1930-33, teachers, writers, artists, thinkers, political leaders - the national brain were liquidated, imprisoned, or deported. Later an offensive against the national churches - the 'soul' of Ukraine was committed, when between 1926 and 1932, the Ukrainian Orthodox Autocephalous Church, its Metropolitan (Lypkivsky) and 10,000 clergy were liquidated. In 1945, when the Soviets established themselves in Western Ukraine, a similar fate was meted out to the Ukrainian Catholic Church. The next step was starvation to death of a significant part of the Ukrainian peasantry - the repository of the national spirit of Ukraine; followed by the fragmentation of the Ukrainian people at once by the addition to Ukraine of foreign peoples and by the dispersion of the Ukrainians throughout Eastern Europe. In this way, ethnic unity was destroyed [17, p. 32-35].

The ICC noted that the existence of intent to commit genocide and knowledge can be inferred from relevant facts and circumstances [8]. In other words, genocidal intent does not necessarily have to be fixed in documents or expressed in public speeches. Moreover, as it was ruled by the International Court of Justice (ICJ) in BosniaHerzegovina v. Yugoslavia case, it is "sufficient that the State was aware, or should normally have been aware, of the serious danger that acts of genocide would be committed" [13].

The International Criminal Tribunal for Rwanda (ICTR) also confirmed the rule that the existence of intent to commit genocide may be inferred "from the material evidence submitted to the Chamber, including the evidence which demonstrates a consistent pattern of conducts by the Accused" (Rutaganda Case, 1999), or “a perpetrator's mens rea may be inferred from his actions" (Prosecutor $v$. Semanza Case) [10, p. 13]. In Kayishema and Ruzindana Case, the ICTR Trial Chamber stated that as the intent might be difficult to determine, the accused's "actions, including circumstantial evidence, however may provide sufficient evidence of intent," and that "intent can be inferred either from words or deeds and may be demonstrated by a pattern of purposeful action" [10, p. 14]. There exist numerous examples of such genocidal purposeful 
actions by perpetrators in all the three cases of genocide.

The intent of the All-Union Communist Party of Bolsheviks (AUCPB) to exterminate the Ukrainians in part may be inferred from its resolutions and directives, as well as from its conducts and their consequences. On 22 January 1933, Stalin sent a secret directive ordering Ukraine, Belarus, and the neighboring regions of the RSFSR to prevent the exodus of peasants from the Kuban and Ukraine to the nearby regions of Russia and Belarus. The directive insisted that the exodus was organized by Polish agents and enemies of the Soviet regime in order to agitate against collective farms and the Soviet system. Local authorities and the OGPU were ordered to prevent mass departures and to immediately arrest the "peasants" of Ukraine and North Caucasus who made their way north [24, p. 224; 12, p. 193]. Roman Serbyn considers this directive to be "perhaps the best available evidence of the dictator's genocidal intent against the Ukrainian people" [24, p. 224].

Among few international law scholars who analysed Stalin's famine as a test case for the intent requirement thus "determining whether the millions of Ukrainian peasant deaths in 1932 constituted genocide, was Th. W. Simon. For this, he attempted to determine whether the Soviet dictator Joseph Stalin intended to carry out the killings. While agreeing with Simon that "more often... mass atrocities occur because of indirect and implicit plans made, not simply by individuals, but within organizational state structures" [26, p. 71], I cannot agree with him that the case of Stalin fails to meet the intent requirement for the crime of genocide, because, as Th. W. Simon writes, scholarly uncovering of Soviet sins fails "to locate a 'master plan' for what would be a vast economic experiment in repression - and - indeed argues that probably there was no such plan" [26, p. 70]. However, the ICTR ruled in Kayishema and Ruzindana Case in 1999 that a specific plan to destroy does not constitute an element of genocide, however "it is not easy to carry out genocide without such a plan, or organization [10, p. 14]. As B. Lieberman stressed, "there was not a single plan for genocide created far in advance of the Holocaust" [18, p. 161] either.

Th. W. Simon was most likely not familiar with the Central Committee (CC) of the AUCPB and Council of People's Commissars (CPC) resolutions and directives which were not only economic ones but had a clear link with Ukrainian national issue. One of such resolutions, of the CC of AUCPB and CPC of USSR, issued on 14 December 1932 and entitled "On grain-collection in Ukraine, the North Caucasus, and in the Western region" demonstrates that the government was scared of the results of Ukrainization. It was believed that this policy of Ukrainization was implemented beyond the "allowed margins" and grain collection was to become a method of suppressing social and national resistance. This resolution clearly testifies that there was a direct connection between the policy of grain storage and the results of Ukrainization. In order to eliminate resistance to grain storage by kulak elements and their party and non-party flunkeys, CC of AUCPB and CPC of the USSR approved inter alia to propose $\mathrm{CC}$ of the Communist Party of bolsheviks $(\mathrm{CPb})$ and $\mathrm{CPC}$ of the Ukrainian SSR to pay serious attention to the proper implementation of Ukrainization, to eliminate its mechanical realization, to expel Petliurites and other bourgeois and nationalistic elements from party and state organizations, to thoroughly choose and bring up Ukrainian Bolshevik cadres, to guarantee systematic party leadership and control over the implementation of Ukrainization [22, p. 247].

Knowledge test in the mental element of genocide As stated above, the mental element of the crime of genocide also includes a knowledge test. For the purposes of Article 30 of the Rome Statute of ICC, 'knowledge' means awareness that a circumstance exists or a consequence will occur in the ordinary course of events [23]. Th. W. Simon does not draw any distinction between intent and knowledge and claims that "the defendants must have had the requisite intent in the sense that they had or should have had knowledge of the alleged crime" [26, p. 73]. However, in Prosecutor v. Acayesu Case (1998), the ICTR distinguished between knowledge and intent, as individuals could know that their acts contributed to the destruction of a group and yet not have the intent or specific goal of destroying: "The offender is culpable because he knew or should have known that the act committed would destroy, in whole or in part, a group" [10, p. 12]. On the other hand, Payam Akhvan notes the importance of seeking the destruction in whole or in part of a group by the accused, arguing that it is not sufficient that the accused knows that his acts will, inevitably or probably, result in the destruction of the group in question [1, p. 44]. Put another way, an accused could not be found guilty of genocide if he himself did not share the goal of destroying in part or in whole a group even if he knew that he was contributing to or through his acts might be contributing to the partial or total destruction of a group [14, paras 85-86]. 
Stalin and his henchmen knew what the consequences of the famine would be for the Ukrainians and they foresaw and planned these consequences. Even those scholars who deny that the famine in Ukraine was genocide stress, "Ukrainian nationalism was attacked because it was perceived as a threat to Stalin's procurement policies" [12, p. 194], which in legal terms means culpability, the intent to destroy on national basis.

\section{Timing of genocide}

Closely related to the intent element is the timing issue of genocide. The intent of the Young Turks Ittihadists to destroy Armenians appeared at the very outset when orders were given for deportations. Armenians started to be vulnerable as early as in 1894-1896 and in 1909 massacres, long before the culmination of the Armenian genocide in 1915.

Similarly, the Holocaust has not started when gas cameras were established. H. Fein argues that intent to exterminate Jews appeared earlier, as they started to be collective victims when Nazi Germany was systematically slaughtering Jews almost three months before the start of operations in the first extermination camp and more than four months before the Wannsee Conference, and British intelligence had a basic grasp of Nazi intentions towards Jews in the Soviet territories [5, p. 96-97; 9, p. 18].

Some scholars argue that the Kristallnacht (Night of Broken Glass) on November 9-10, 1938 was "a proto-genocide assault" that targeted Jewish properties, residences, and persons. Several dozen Jews were killed and some 30,000 male Jews were rounded up and imprisoned in concentration camps [15, p. 237]. As Vahakn N. Dadrian writes, the intent of the Nazis was on resettling rather than literally exterminating even beyond the year 1940 [7, p. 41]. Only after 1942, when death camps were established, the intent to destroy Jews became evident.

V. N. Dadrian uses the term "rudimentary stages of genocide" for the period when "the leadership of the Armenian nation throughout the length and breadth of the Ottoman empire was subjected to an array of tortures..." [7, p. 50]. Similarly, at the rudimentary stages of the Soviet genocide in Ukraine, the Ukrainians were exterminated selectively: first intelligentsia and clergy, later the peasantry. The culmination of Stalin's genocide against the Ukrainians was "the fateful year of 1933" when "physically exhausted after several years of struggle and privation, the farmers of the Ukrainian SSR and the ethnically Ukrainian regions of the RSFSR were most vulnerable to the new onslaught of the communist regime's destructive actions. During the winter, spring, and into the summer of 1933, uncounted millions died of hunger, cold, and the maladies that accompanied them. Previous repressions were intensified. 'Dekulakization' (no real kulaks were left) and deportations continued, although on a smaller scale and for mostly political reasons. Arrests, beatings, and all sorts of cruelties thrived as before, only now the victims were weaker and less capable of resistance" [24, p. 224].

\section{The perspective of perpetrators}

There is much in common between analyzed genocides in terms of perpetrators or the agents of genocide who had the specific intent to destroy the relevant groups. One cannot but agree with Th. W. Simon that "the organizations and not individuals are the primary agents of the crime of genocide" [26, p. 4]. Stalin as well as Hitler would hardly be able to commit genocides not having been leaders of huge political parties.

On the level of perpetrators, similar to the cases of the Armenian genocide and the Holocaust, the Holodomor was conceived, organised, and implemented by a "monopolistic political party." V. N. Dadrian describes the cases of the Armenian and the Jewish genocide to be "twin genocides" the state organizations in the Third Reich and the Ottoman Empire were almost reduced to irrelevance as the Nazis and the Ittihadists gained optimal control of these organizations, including the key governmental agencies, such as cabinet of ministries and legislative bodies. V. N. Dadrian claims in his study that "even though by doing this they overwhelmed and gained full control of the organs of the state, they essentially functioned as party fanatics and emerged as the actual authors of the two respective genocides" [7, p. 60].

Similarly, the Communist Party of Bolsheviks of the Soviet Union was the actual author of the Holodomor in Ukraine and held control over all other state and legislative bodies. Paraphrasing V. N. Dadrian and transferring his argument about shifting state power to political parties in the Ottoman Empire and in Nazi Germany, I would similarly argue that in order to examine and comprehend the overt as well as covert aspects of these genocides it is necessary to examine the leadership, ideology, structure, and inner workings of political parties that become "substitutes for the governments they supplanted and usurped" [7, p. 55]. The Central Committee of the AUCPB played the same role in the Holodomor as the Ittihad Party Central Committee in the Armenian genocide or the National Socialist Party in Nazi Germany. 


\section{Conclusion}

The comparison of the three genocides under analysis revealed a number of dissimilarities and similarities in the mens rea element in the compared cases of genocide. In all the three genocides, there was a specific intent to destroy a relative group, either in whole (the Armenians and Jews) or in part (the Ukrainians); however, the nature of the intent differed in the three genocides. While the intent was explicit in the Armenian and in the Jewish cases, the intent was implicit in the Holodomor and may be inferred from resolutions and directives of the AUCPB and $\mathrm{CPC}$, as well as from their conduct and consequences. Thus even under the strictest definition of genocide, the Holodomor of the Ukrainians may be placed among the three most significant such acts in the first half of the $20^{\text {th }}$ century - together with the Ottoman Turk genocide of the Armenians and the Holocaust [3, p. 138].
As it has been highlighted, a key commonality between the genocides perpetrated in the Ottoman Empire, the Soviet Union, and the Third Reich was that in each case state organization was substituted by hegemony of a ruling party, respectively, the Ittihadists, the Communists, and the Nazis, who were the actual authors of dolus specialis of the three genocides.

The comparative analysis proved that "all genocides are simultaneously unique and analogous. The similarities and dissimilarities can be equally instructive in understanding how genocides arise, how they function, and, perhaps, how they can be prevented" [2, p. 14]. The importance of comparing cases of genocide is evident - if lessons from the past are not heeded and genocide is not punished, aggressors will continue to be emboldened, as can be seen in Ukraine's eastern regions and in the Crimea, where the successor state of the Soviet Union - the Russian Federation - persists in attacking Ukraine and its people.

\section{References}

1. Akhavan, P. (2012). Reducing Genocide to Law: definition meaning, and the ultimate crime. Retrieved from http://go.utlib. ca/cat/8392844 (last accessed: 27.01.2019).

2. Alvarez, A. (2001). Governments, citizens, and genocides a comparative and interdisciplinary approach. Bloomington and Indianapolis: Indiana University Press.

3. Bartrop, P. R., \& Totten, S. (2009). The History of Genocide An Overview. The Genocide Studies Reader. S. Totten, \& P. R. Bartrop (Eds). New York and London: Routledge.

4. Boot, M. (2002). Genocide, Crimes against Humanity, War Crimes: Nullum Crimen Sine Lege and the Subject Matter Jurisdiction of the International Criminal Court. Antwerpen, Oxford, New York: Intersentia.

5. Breitman, R. (1998). Official Secrets: What the Nazis Planned, What the British and American Knew. New York: Hill and Wang; as cited in Fein, H. (2001). Denying Genocide from Armenia to Bosnia.

6. Conquest, R. (1986). The Harvest of Sorrow: Soviet Collectivization and the Terror-Famine. New York: Oxford University Press.

7. Dadrian, V. N. (2005). Patterns of Twentieth Century Genocides: The Armenian, Jewish, and Rwandan Cases. Genocide and Mass Violence in the 20 th and $21^{\text {st }}$ Centuries: An Introduction. Criteria, Common Elements, and Patterns. Comparative Genocide Studies (Vol. 1). C. P. Scherrer (Ed.). Moers: IFEK-IRECOR.

8. Elements of Crimes. (2001). [International Criminal Court]. Retrieved from https://www.icc-cpi.int/NR/rdonlyres/336923D8A6AD-40EC-AD7B-45BF9DE73D56/0/ElementsOfCrimesEng.pdf (last accessed: 27.01.2019).

9. Fein, H. (2001). Denying Genocide from Armenia to Bosnia. A lecture delivered at the London School of Economics and Political Science on 22 January 2001. Occasional Papers in Comparative and International Politics (Vol. 1). New York, USA: Institute for the Study of Genocide.

10. Human Rights Watch. (2004). Genocide, War Crimes and Crimes against Humanity: Topical Digests of the Case Law of the International Criminal Tribunal for Rwanda and the International Criminal Tribunal for the Former Yugoslavia.

11. Graziosi, A. (2015). The Impact of Holodomor Studies on the Understanding of the USSR. Contextualizing the Holodomor:

The Impact of Thirty Years of Ukrainian Famine Studies. A. Makuch, \& F. E. Sysyn (Eds). Edmonton, Toronto: Canadian Institute of Ukrainian Studies Press.

12. Green, B. B. (2001). Stalinist Terror and the Question of Genocide: The Great Famine. Is the Holocaust Unique? Perspectives on Comparative genocide. A. S. Rosenbaum (Ed.). Westview Press.

13. Bosnia-Herzegovina v. Yugoslavia case. (1996). [International Court of Justice]. Retrieved from http://www.icj-cij.org/ presscom/index.php?pr=1897\&pt $=1 \& \mathrm{p} 1=6 \& \mathrm{p} 2=1 \quad$ (last accessed: 27.01.2019).

14. The Prosecutor v. Goran Jelisi'c, Case No. IT-95-10. (1999). [International Criminal Tribunal for the Former Yugoslavia]. Retrieved from http://www.icty.org/x/cases/jelisic/tjug/en/jeltj991214e.pdf (last accessed: 27.01.2019).

15. Jones, A. (2006). Genocide: A Comprehensive Introduction. London and New York: Routledge.

16. Kul'chyts'kyi, S. (2015). The Holodomor of 1932-1933: How and Why. Contextualizing the Holodomor: The Impact of Thirty Years of Ukrainian Famine Studies. A. Makuch, \& F. E. Sysyn (Eds). Edmonton, Toronto: Canadian Institute of Ukrainian Studies Press.

17. Lemkin, R. (2009). Soviet Genocide in Ukraine. Rafael Lemkin. Soviet Genocide in Ukraine. Article in 28 languages. Roman Serbyn (Ed.). Kyiv: Maisternia Knyhy.

18. Lieberman, B. (2013). The Holocaust and genocides in Europe. Lnd., New Delhi, N.Y., Sydney: Bloomsbury.

19. Mace, J. E. (1990). Genocide by Famine; Ukraine in 1932 1933. State Violence and Ethnicity. Pierre L. van den Berghe (Ed.). Niwot, Colo.: University Press of Colorado.

20. Mace, J. E. (1997). Soviet Man-Made Famine in Ukraine. Century of Genocide: Eye Witness Accounts and Critical Views. Samuel Totten, William S. Parsons, \& Israel W. Charny (Eds). New York: Garland Publishing.

21. Naimark, N. M. (2015). How the Holodomor Can Be Integrated into our Understanding of Genocide. Contextualizing the Holodomor: The Impact of Thirty Years of Ukrainian Famine Studies. A. Makuch, \& F. E. Sysyn (Eds). Edmonton, Toronto: Canadian Institute of Ukrainian Studies Press.

22. Resolution of the CC AUCP(B) and CPC USSR on grain procurements in Ukraine, the North Caucasus and the Western 
Oblast. (2008). Holodomor of 1932-33 in Ukraine. Excepts (pp. 65-68); as cited in Bohdan Klid, \& Alexander J. Motyl (Eds). (2012). The Holodomor reader: a sourcebook on the Famine of 1932-1933 in Ukraine. Edmonton, Toronto: Canadian Institute of Ukrainian Studies Press.

23. Rome Statute of the International Criminal Court. (1998). Retrieved from https://www.icc-cpi.int/nr/rdonlyres/ea9aeff75752-4f84-be94-0a655eb30e16/0/rome_statute_english.pdf (last accessed: 27.01.2019).

24. Serbyn, R. (2010). Holodomor: The Ukrainian Genocide. Central and Eastern European Online Library PISM Series, 1, 205-230. Retrieved from https:/www.ceeol.com/search/article-detail?id= 86294 (last accessed: 27.01.2019).

25. Serbyn, R. (2009). Lemkin on the Ukrainian Genocide. Journal of International Criminal Justice, 7, 123-130.
26. Simon, Th. W. (2007). The laws of genocide: prescriptions for a just world. Westport, Connecticut, London: Praeger Security International.

27. Sydnor, Ch. W. Jr. (1998). Executive Instincts, Reinhard Heydrich and the Planning for the Final Solution. The Holocaust and History. Michael Berenbaum, \& Abraham J. Peck (Eds). Bloomington, IN: Indiana University Press; as cited in Simon, Th. W. (2007). The laws of genocide: prescriptions for a just world. Westport, Connecticut, London: Praeger Security International.

28. Sysyn, F. (1999). The Ukrainian famine of 1932-3: the Role of the Ukrainian Diaspora in Research and Public Discussion. Studies in comparative genocide. Levon Chorbajaian and George Shirinian (Eds). Houndmills, Basingstoke, Hampshire and London: Macmillan Press Ltd.

Антонович М. М.

\section{СПЕЦІАЛЬНИЙ НАМIР (DOLUS SPECIALIS) У ВІРМЕНСЬКОМУ ГЕНОЦИДІ, ГОЛОДОМОРІ ТА ГОЛОКОСТІ: ПОРІВНЯЛЬНИЙ АНАЛІЗ}

Хоч порівняльні дослідження геноцидів як друге покоління студій про геноцид розвиваються вже понад два десятиліття, Голодомор як злочин геноциду, вчинений сталінським режимом, майже не було досліджено в порівняльному аспекті. У цій статті авторка простежує причини цього і пропонує порівняльний аналіз Голодомору з іншими геноцидами першої половини ХХ ст., а саме з Вірменським геноцидом в Оттоманській імперії і Голокостом у нацистській Німеччині. Авторка порівнює ці три геноциди як злочини згідно з міжнародним правом в аспекті суб'єктивних (ментальних, mens rea) елементів геноциду, характерних для кожного з них, зазначаючи відмінні та спільні особливості в спеціальному намірі (dolus specialis) цих злочинів. На відміну від Вірменського геноциду і Голокосту, де був намір знищити відповідні національні групи цілком, у Голодоморі був намір знищити українську національну групу частково з метою ослаблення іiі, оскільки вона була занадто численною для цілковитого знищення. Іншою відмінністю було те, що намір знищити вірмен та євреїв був експліцитним, в основному сформульованим у документах, у той час як намір вчинити Голодомор був імпліцитним, прямо не вираженим у документах. Однак відповідно до рішень Руандійського та Югославського кримінальних трибуналів $a d$ hoc і Міжнародного кримінального суду намір вчинити геноцид можна також вивести з відповідних фактів і обставин. Авторка доходить висновку про те, що основним спільним елементом геноцидів, вчинених в Оттоманській імперії, Радянському Союзі і в Третьому Рейху, було те, що державна організація була підмінена гегемонією керівної партії: іттихадистами, комуністами, нацистами (the Ittihadists, the Communists, and the Nazis). Вказано на важливість порівняльних досліджень злочинів геноцидів, оскільки, якщо не винести уроків 3 минулих геноцидів і не покарати за них, історія повториться, як це можемо бачити на сході та півдні України (в Криму), де Російська Федерація як держава-правонаступниця Радянського Союзу, не покараного за Голодомор-геноцид, і далі знищує українську націю.

Ключові слова: Вірменський геноцид, Голодомор, Голокост, суб'єктивні (ментальні) елементи геноциду, спеціальний намір (dolus specialis) геноциду. 